\title{
Paper and Paper Products and Wood and Wood Products Sectors Competition Analysis: BRICS Countries and Turkey
}

\author{
Kadri Cemil AKYÜZ* IIlker AKYÜZ \\ Karadeniz Technical University, Department of Forest Industry Engineering Kanuni Campus, Trabzon/Türkiye
}

How to cite: Akyüz, K.C. \& Akyüz İ. (2020). Paper and paper products and wood and wood products sectors competition analysis: BRICS countries and Turkey. J. Anatolian Env. and Anim. Sciences, 5(5), 814-818.

Atıf yapmak için: Akyüz, K.C. \& Akyüz İ. (2020). Kağıt-kağıt ürünleri sanayi ve ahşap-ahşap ürünleri sanayi sektöründe rekabet analizi: BRICS ülkeleri ve Türkiye. Anadolu Çev. ve Hay. Dergisi, 5(5), 814-818.

D : https://orcid.org/0000-0003-0049-6379 iD : https://orcid.org/0000-0003-4241-1118

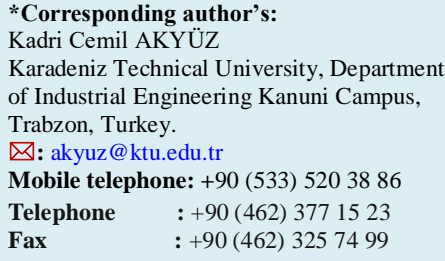

\begin{abstract}
Financial crises on a world scale cause the emergence of new economic structures and powers. While the financial efficiency of developed countries decreases, developing countries are increasing their positions. BRIC (Brazil, Russia, India and China), which emerged as an alternative economic power after the financial crisis in 2008, started to be known as BRICS countries with the addition of South Africa in 2011 and became an important economic structure. Its economic and demographic strength of thanks and wishing to take part in the active position in the world Turkey is willing to take part in the BRICS. Determination of Turkey's infrastructure sector as competitive with these countries is extremely important. In this study of the important sectoral groups of Turkey Paper and Paper Products and Wood and Wood Products Sector is intended to determine whether a location opposite of how the BRICS countries. Revealed Comparative Advantages approach was used in the study covering the years between 2010-2019. As a result of the study, countries were compared at year level and superior sectoral structures were determined.
\end{abstract}

Keywords: BRICS, Turkey, paper-paper products, wood-wood products, revealed comparative advantages.

\section{Kağıt-Kağıt Ürünleri Sanayi ve Ahşap-Ahşap Ürünleri Sanayi Sektöründe Rekabet Analizi: BRICS Ülkeleri ve Türkiye}

*Sorumlu yazarin:

Kadri Cemil AKYÜZ

Karadeniz Teknik Üniversitesi Orman

Fakültesi Orman Endüstri Mühendisliği

Bölümü, Kanuni Kampusü Trabzon, Türkiye

$\triangle:$ akyuz@ktu.edu.tr

Cep telefonu : +90(533) 5203886

Telefon : : $+90(462) 3771523$

Faks $\quad:+90(462) 3257499$
Öz: Dünya ölçeğindeki finansal krizler, yeni ekonomik yapıların ve güçlerin ortaya çıkmasına neden olmuştur. Gelişmiş ülkelerin finansal verimliliği düşerken, gelişmekte olan ülkeler konumlarını yükseltmektedir. 2008 yılındaki finansal krizin ardından alternatif bir ekonomik güc olarak ortaya çıkan BRIC (Brezilya, Rusya, Hindistan ve Çin), 2011 yılında Güney Afrika'nın da eklenmesiyle BRICS ülkeleri olarak bilinmeye başladı ve önemli bir ekonomik yapı haline geldi. Ekonomik ve demografik gücüyle dünyada aktif pozisyonda yer almak isteyen Türkiye, BRICS'e katılmaya isteklidir. Türkiye'nin sektörel yapısının bu ülkelerle rekabet konumunun belirlenmesi son derece önemlidir. Bu çalışmada Türkiye Kağıt ve Kağıt Ürünleri ile Ağaç ve Ağaç Ürünleri Sektörünün BRICS ülkelerine karşı nasıl bir konumda olduğunun belirlenmesi amaçlanmıştır. 2010-2019 yıllarını kapsayan çalışmada Karşılaştırmalı Üstünlükler yaklaşımı kullanılmıştır. Çalışma sonucunda ülkeler yıl bazında karşılaştırılmış ve üstün sektörel yapılar tespit edilmiştir.

$\underline{\text { Anahtar kelimeler: BRICS, Türkiye, kağıt-kağıt ürünleri, ahșap-ahșap ürünleri, rekabet analizi. }}$

\section{INTRODUCTION}

With the end of the cold war, countries in different parts of the world began to become visible with the economic power they caught, and they argued that an order in which many powers would be effective, not just one power, was adopted in the world economy (Chen, 2003;
Poyraz, 2019). The conflicts, especially due to lack of resources, forced the formation of different economic unions and created alternative economic power centers to the USA and liberal economic thought. China, Russia, Brazil, India and Turkey adopted to create alternative to the IMF and World Bank (Ateş, 2012; Çelik, 2017). 
Established in 2006 under the name of BRIC countries (Brazil, Russia, India, China) and later named BRICS with the addition of South Africa in 2011, the formation created an alternative center of attraction and new cooperation opportunities for developing countries (Önder, 2019). In 2001, according to the report published by Jim o Neill, the chairman of the board of directors of Goldman Sachs, an international investment bank, it took its place in the economic structure (O'Neill, 2001; Sezer, 2018). In a report prepared in 2003, in less than 40 years, BRIC countries; It has been hypothesized that France, Germany, Italy, Japan, the UK and the USA will catch up with the G6 countries and then these countries will become the main engine of new demand growth and spending power that will balance the slowing growth and population in developed economies (Atabay Baytar, 2012). According to the economic predictions made for the near future, it is stated that the BRICS countries will surpass the G7 countries in 2035 (Öniş and Kutlay, 2015), and they will be among the top 10 economies of the world in 2050 (Wilson and Purushothaman, 2003). The last 20 years have shown that Turkey's economic success is also considered one of the leading countries in 2050 is stated to be Turkey. Therefore it emphasized the necessity of Turkey's inclusion in this association and Turkey has expressed he wanted to be a member of this mechanism in 2018 .

Turkey's membership of BRICS searching for new markets, and technological partnerships will help support their desire to become a global actor. Therefore, Turkey should revise the existing economic structure. When examining the literature of Turkey and the BRICS member countries seem to be limited studies comparing economic performance. In this study, it is aimed to determine the competitive position of Paper and Paper Products Industry and Wood and Wood products industry groups, which are sub-industrial groups of the Forest Products Industry Sector, against BRICS countries. It is important for the future of the country to support industrial groups that have a high competitive position against BRICS countries and to plan their resource use in this direction.

Paper and Paper Products Industry and Wood and Wood Products Industry in Foreign Trade: The foreign trade figures of the countries within the scope of the study in the field of paper and paper products and wood and wood products are given in the tables below.

Table 1 show that Brazil has a significant foreign trade surplus at both sectoral levels. When the situation is evaluated in terms of the years analyzed, it is seen that the foreign trade surplus in the field of paper and paper products increased by $143 \%$. The increase in the foreign trade surplus in the wood and wood products industry is around 55\%. Paper and paper products industry realized approximately $0.8 \%$ of Brazil's average exports between 2010 and 2019, while this rate is $1 \%$ for the wood and wood products industry. A portion of $1.1 \%$ of the average paper exports made throughout the world within the specified years was realized by Brazil. In the field of wood and wood products industry, approximately $2.2 \%$ of the average export realized between 2010 and 2019 was made by Brazil.

Table 1. Brazil's export-import level by years (1,000 dollars).

\begin{tabular}{lccccccc}
\hline \multicolumn{3}{c}{ Paper and Paper Products } & \multicolumn{3}{c}{ Wood and Wood Products } \\
\hline Years & Export & Imports & $\begin{array}{c}\text { Current } \\
\text { Account } \\
\text { Balance }\end{array}$ & Years & Export & Imports & $\begin{array}{c}\text { Current } \\
\text { Account } \\
\text { Balance }\end{array}$ \\
\hline 2010 & 2.008 .555 & 1.540 .653 & 467.902 & 2010 & 1.917 .872 & 133.087 & 1.784 .785 \\
2011 & 2.187 .577 & 1.754 .203 & 433.374 & 2011 & 1.900 .096 & 176.455 & 1.723 .641 \\
2012 & 1.951 .228 & 1.606 .042 & 345.186 & 2012 & 1.887 .658 & 167.639 & 1.720 .019 \\
2013 & 1.970 .194 & 1.505 .819 & 464.375 & 2013 & 2.003 .924 & 144.449 & 1.859 .475 \\
2014 & 1.922 .181 & 1.441 .538 & 480.643 & 2014 & 2.243 .112 & 150.617 & 2.092 .495 \\
2015 & 2.020 .964 & 957.817 & 1.063 .147 & 2015 & 2.271 .395 & 116.236 & 2.155 .159 \\
2016 & 1.871 .020 & 738.456 & 1.132 .564 & 2016 & 2.361 .479 & 98.880 & 2.262 .599 \\
2017 & 1.013 .080 & 838.173 & 1.074 .907 & 2017 & 2.779 .920 & 96.932 & 2.682 .988 \\
2018 & 2.072 .495 & 883.457 & 1.189 .038 & 2018 & 3.182 .252 & 100.556 & 3.081 .696 \\
2019 & 1.986 .916 & 846.891 & 1.140 .025 & 2019 & 2.886 .205 & 108.418 & 2.777 .787 \\
\hline
\end{tabular}

Foreign trade data of Russia can be seen in Table 2. As a result of the evaluation made, it is seen that the foreign trade deficit in the field of paper and paper products between 2010 and 2017 turned into a foreign trade surplus in 2018 and 2019. This change shows that Russia is turning into a production center in the paper and paper products sector. When the level of exports in the field of paper and paper products is analyzed, it corresponds to approximately $0.4 \%$ of Russia's overall export level in terms of the average of all years. Russia realizes $1.2 \%$ of the paper exports made worldwide. When the data of the wood and wood products sector are examined, an increasing foreign trade surplus of Russia in all years draws attention. The foreign trade surplus, which increased approximately by 53\% between 2010 and 2019, shows Russia's effectiveness in this area. The wood and wood products industry sector, which has a share of $1.7 \%$ in Russia's total foreign trade average, constitutes $5.6 \%$ of the world's wood and wood products exports.

Table 2. Russia's export-import level by years (1,000 dollars).

\begin{tabular}{cccccccc}
\hline \multicolumn{3}{c}{ Paper and Paper Products } & \multicolumn{3}{c}{ Wood and Wood Products } \\
\hline Years & Export & Imports & $\begin{array}{c}\text { Current } \\
\text { Account } \\
\text { Balance }\end{array}$ & Years & Export & Imports & $\begin{array}{c}\text { Current } \\
\text { Account } \\
\text { Balance }\end{array}$ \\
\hline 2010 & 1.457 .976 & 3.844 .758 & -2.386 .782 & 2010 & 6.093 .699 & 860.844 & 5.232 .855 \\
2011 & 1.732 .652 & 4.309 .085 & -2.576 .433 & 2011 & 6.973 .754 & 1.087 .167 & 5.886 .587 \\
2012 & 1.924 .464 & 3.748 .744 & -1.824 .280 & 2012 & 6.734 .568 & 1.450 .095 & 5.284 .473 \\
2013 & 2.055 .067 & 3.814 .418 & -1.759 .351 & 2013 & 7.330 .193 & 1.653 .171 & 5.677 .022 \\
2014 & 2.260 .193 & 3.542 .705 & -1.282 .512 & 2014 & 7.763 .748 & 1.323 .914 & 6.439 .834 \\
2015 & 1.790 .874 & 2.250 .991 & -460.117 & 2015 & 6.151 .899 & 691.874 & 5.460 .025 \\
2016 & 1.899 .540 & 2.255 .626 & -356.086 & 2016 & 6.523 .925 & 601.922 & 5.922 .003 \\
2017 & 2.197 .132 & 2.404 .796 & -207.664 & 2017 & 7.901 .564 & 657.998 & 7.243 .566 \\
2018 & 2.737 .863 & 2.653 .242 & 84.621 & 2018 & 9.009 .168 & 707.265 & 8.301 .903 \\
2019 & 2.491 .263 & 2.454 .115 & 37.148 & 2019 & 8.619 .543 & 616.044 & 8.003 .499 \\
\hline
\end{tabular}

The data of India in the field of paper and paper products industry and wood and wood products industry are shown in Table 3. India has a significant foreign trade deficit in both product groups (Table 3). Although the foreign trade deficit in the field of paper and paper products 
has decreased over the years, the deficit in wood and wood products has gradually increased. In India's average export, the paper and paper products sector is $0.4 \%$, and the wood and wood products sector is $0.1 \%$. In the evaluation made by taking into account the world export figures, it is seen that India has a share of $0.7 \%$ in the paper and paper products sector and $0.2 \%$ in the wood and wood products sector.

Table 3. India's export-import level by years (1,000 dollars).

\begin{tabular}{cccccccc}
\hline \multicolumn{3}{c}{ Paper and Paper Products } & \multicolumn{3}{c}{ Wood and Wood Products } \\
\hline Years & Export & Imports & $\begin{array}{l}\text { Current } \\
\text { Account } \\
\text { Balance }\end{array}$ & Years & Export & Imports & $\begin{array}{c}\text { Current } \\
\text { Account } \\
\text { Balance }\end{array}$ \\
\hline 2010 & 784.177 & 1.887 .451 & -1.103 .274 & 2010 & 163.784 & 1.697 .604 & -1.533 .820 \\
2011 & 906.988 & 2.454 .710 & -1.547 .722 & 2011 & 220.651 & 2.410 .817 & -2.190 .166 \\
2012 & 930.360 & 2.266 .894 & -1.336 .534 & 2012 & 258.874 & 2.606 .741 & -2.347 .867 \\
2013 & 1.139 .895 & 2.364 .880 & -1.224 .985 & 2013 & 351.496 & 2.680 .339 & -2.328 .843 \\
2014 & 1.115 .993 & 2.610 .041 & -1.494 .048 & 2014 & 353.812 & 2.703 .642 & -2.349 .830 \\
2015 & 1.127 .113 & 2.425 .519 & -1.298 .406 & 2015 & 427.377 & 2.435 .878 & -2.008 .501 \\
2016 & 1.183 .920 & 2.662 .456 & -1.478 .536 & 2016 & 400.748 & 2.145 .530 & -1.744 .782 \\
2017 & 1.284 .054 & 3.069 .063 & -1.785 .009 & 2017 & 415.073 & 2.186 .864 & -1.771 .791 \\
2018 & 1.827 .352 & 2.994 .535 & -1.167 .183 & 2018 & 435.525 & 2.227 .212 & -1.791 .687 \\
2019 & 2.061 .320 & 2.886 .570 & -825.250 & 2019 & 477.641 & 2.178 .456 & -1.700 .805 \\
\hline
\end{tabular}

The foreign trade figures of China at both sector levels are shown in Table 4.

Table 4. China's export-import level by years (1,000 dollars).

\begin{tabular}{cccccccc}
\hline \multicolumn{3}{c}{ Paper and Paper Products } & \multicolumn{4}{c}{ Wood and Wood Products } \\
\hline Years & Export & Imports & $\begin{array}{c}\text { Current } \\
\text { Account } \\
\text { Balance }\end{array}$ & Years & Export & Imports & $\begin{array}{c}\text { Current } \\
\text { Account } \\
\text { Balance }\end{array}$ \\
\hline 2010 & 9.561 .194 & 4.611 .778 & 4.949 .416 & 2010 & 9.651 .544 & 11.234 .863 & -1.583 .319 \\
2011 & 12.905 .511 & 5.054 .829 & 7.850 .682 & 2011 & 11.354 .387 & 15.857 .712 & -4.503 .325 \\
2012 & 13.721 .805 & 4.596 .226 & 9.125 .579 & 2012 & 12.315 .248 & 14.937 .027 & -2.621 .779 \\
2013 & 15.987 .710 & 4.372 .835 & 11.614 .875 & 2013 & 12.748 .095 & 18.768 .839 & -6.020 .744 \\
2014 & 17.818 .529 & 4.308 .838 & 13.509 .691 & 2014 & 14.469 .960 & 22.797 .545 & -8.327 .585 \\
2015 & 18.849 .401 & 4.046 .927 & 14.802 .474 & 2015 & 14.211 .187 & 18.627 .016 & -4.415 .829 \\
2016 & 18.172 .109 & 3.944 .806 & 14.227 .303 & 2016 & 13.613 .182 & 19.596 .941 & -5.983 .759 \\
2017 & 18.417 .669 & 4.985 .630 & 13.432 .039 & 2017 & 13.693 .413 & 23.411 .325 & -9.717 .912 \\
2018 & 19.460 .630 & 6.201 .170 & 13.259 .460 & 2018 & 14.888 .332 & 24.914 .414 & -10.026 .082 \\
2019 & 22.008 .827 & 5.265 .825 & 16.743 .002 & 2019 & 13.410 .436 & 21.976 .449 & -8.566 .013 \\
\hline
\end{tabular}

When the data in Table 4 are examined, it is noteworthy that the foreign trade figures are high. Especially in recent years, China, which has become the production center of the world, has created trade activity at the level of sectors. The foreign trade volume of paper and paper products in 2010 reached 27 billion dollars in 2019 from approximately 14 billion dollars. Within the same period, the foreign trade surplus increased approximately 4 times. On average, $0.7 \%$ of all exports made by China in the years 2010-2019 were realized by the paper and paper products industry sector. Considering the average of world paper exports for the years 2010-2019, it is seen that $10 \%$ of it was made by China. Having a foreign trade deficit in the field of wood and wood products, China realized an average of $10.1 \%$ of world exports. The share of wood and wood products in China's own exports is $6 \%$ in terms of the 2010-2019 average.

South Africa's foreign trade data are shown in Table 5. Having a negative foreign trade balance in the paper and paper products industry for all years, South Africa is in a position to have a foreign trade surplus in the field of wood and wood products. The paper and paper products industry sector has a $0.8 \%$ share in the country's foreign trade, while the share of wood and wood products in foreign trade is $0.5 \%$. In the world trade, South Africa has a share of $0.4 \%$ in paper and paper products and $0.3 \%$ in wood and wood products.

Table 5. South Africa's export-import level by years (1,000 dollars).

\begin{tabular}{cccccccc}
\hline \multicolumn{7}{c}{ Paper and Paper Products } & \multicolumn{7}{c}{ Wood and Wood Products } \\
\hline Years & Export & Imports & $\begin{array}{c}\text { Current } \\
\text { Account } \\
\text { Balance }\end{array}$ & Years & Export & Imports & $\begin{array}{c}\text { Current } \\
\text { Account } \\
\text { Balance }\end{array}$ \\
\hline 2010 & 910.164 & 992.383 & -82.219 & 2010 & 513.759 & 334.443 & 179.316 \\
2011 & 916.871 & 1.080 .319 & -163.448 & 2011 & 538.660 & 400.081 & 138.579 \\
2012 & 809.829 & 1.048 .274 & -238.445 & 2012 & 471.249 & 400.126 & 71.123 \\
2013 & 733.495 & 1.057 .978 & -324.483 & 2013 & 451.334 & 393.037 & 58.297 \\
2014 & 727.116 & 1.043 .424 & -316.308 & 2014 & 510.265 & 396.521 & 113.744 \\
2015 & 665.762 & 973.476 & -307.714 & 2015 & 500.958 & 375.820 & 125.138 \\
2016 & 635.106 & 896.427 & -261.321 & 2016 & 475.342 & 346.874 & 128.468 \\
2017 & 625.648 & 909.485 & -283.837 & 2017 & 535.495 & 360.382 & 175.113 \\
2018 & 706.252 & 1.076 .186 & -369.934 & 2018 & 588.922 & 382.758 & 206.164 \\
2019 & 595.931 & 1.035 .157 & -439.226 & 2019 & 516.639 & 362.633 & 154.006 \\
\hline
\end{tabular}

Turkey's foreign trade figures in Table 6 are also shown. When the figures in Table 6 are examined, it is seen that both sectors have a positive foreign trade trend. The increase in exports in the paper and paper products industry over the years has an important effect on reducing the foreign trade deficit. Paper and paper products forming part about $1 \%$ of Turkey's trade with Turkey has the capacity to add to the positive change that has industrial economy. Paper and paper products in world trade, which owns a $0.8 \%$ share at the level of Turkey holds the power industry, this rate may increase rapidly. When the foreign trade figures of wood and wood products are examined, it is seen that the balance, which was negative over the years, has moved to positive with the increase in exports. sector, which has a weight of $0.4 \%$ in Turkey's foreign trade is a $0.5 \%$ share of world trade in general.

Table 6. Turkey's export-import level by years (1,000 dollars).

\begin{tabular}{cccccccc}
\hline \multicolumn{3}{c}{ Paper and Paper Products } & \multicolumn{3}{c}{ Wood and Wood Products } \\
\hline Years & Export & Imports & $\begin{array}{c}\text { Current } \\
\text { Account } \\
\text { Balance }\end{array}$ & Years & Export & Imports & $\begin{array}{c}\text { Current } \\
\text { Account } \\
\text { Balance }\end{array}$ \\
\hline 2010 & 1.216 .835 & 2.819 .743 & -1.602 .908 & 2010 & 573.203 & 1.098 .395 & -525.195 \\
2011 & 1.427 .255 & 3.109 .936 & -1.682 .681 & 2011 & 652.927 & 1.427 .786 & -774.860 \\
2012 & 1.033 .096 & 2.882 .665 & -1.849 .569 & 2012 & 657.954 & 1.619 .738 & -961.783 \\
2013 & 1.140 .574 & 3.091 .816 & -1.951 .242 & 2013 & 724.631 & 1.563 .578 & -838.948 \\
2014 & 1.203 .724 & 3.170 .718 & -1.966 .994 & 2014 & 853.305 & 1.487 .632 & -634.328 \\
2015 & 1.185 .524 & 2.683 .944 & -1.498 .429 & 2015 & 692.752 & 1.505 .159 & -812.407 \\
2016 & 1.353 .499 & 2.684 .714 & -1.330 .141 & 2016 & 675.873 & 1.265 .054 & -589.131 \\
2017 & 1.520 .374 & 2.811 .916 & -1.291 .542 & 2017 & 763.956 & 1.132 .785 & -369.895 \\
2018 & 1.715 .787 & 2.749 .839 & -1.034 .052 & 2018 & 826.635 & 827.893 & -1.258 \\
2019 & 1.796 .339 & 2.513 .824 & -717.485 & 2019 & 885.456 & 405.913 & 479.543 \\
\hline
\end{tabular}

\section{MATERIALS AND METHOD}

BRICS countries and Turkey's Paper and Paper Products Industry and Wood \& Wood Products 2010-2019 year study of competition in the industry sector analysis of foreign trade data are used. The data used for analysis was obtained from the TradeMap (2020) website.

In order to measure the competitiveness of the firm, industry and countries, it primarily uses foreign trade data. In our study; The Revealed Comparative Advantage (RCA) method, which was created by Liesner (1958) to 
measure competitiveness and later developed by Balassa (1965) and has been widely used until today, was used. The Balassa index was formulated as follows:

RCAij $=(x i j / X j) /(x i w / X w)$

where;

RCAij; revealed comparative advantage index for the ith goods of the jth country.

xij : jth country's ith exported goods

$\mathrm{Xj}$ : jth country's total exports

xiw : ith goods of the global exports

XW : total global exports

A value less than 1 to be obtained as a result of the analysis made indicates that the country does not have competitive power in terms of comparative advantages explained at the relevant goods level, that is, it has a disadvantage, and a value greater than 1 indicates that it is specialized in that product group, that is, it has announced mutual advantage.

\section{RESULTS AND DISCUSSION}

BRICS countries and Turkey Paper \& Paper Products Industry Sectors competitive analysis of the results in Table 7 are also seen. As a result of the analysis of the competitive power of countries, when the values in Table 7 are examined, it is seen that all countries have averages less than 1 , which is the accepted competitive power value indicator in terms of years average.

Table 7. BRICS countries and Turkey: Paper and Paper Products Industry

\begin{tabular}{lcccccc}
\hline Years & Brazil & Russia & Indian & China & South Africa & Turkey \\
\hline 2010 & 0,896 & 0,330 & 0,320 & 0,545 & 0,992 & 0,962 \\
2011 & 0,829 & 0,325 & 0,292 & 0,660 & 0,824 & 1,027 \\
2012 & 0,903 & 0,412 & 0,361 & 0,752 & 0,920 & 0,761 \\
2013 & 0,904 & 0,533 & 0,376 & 0,804 & 0,857 & 0,834 \\
2014 & 0,938 & 0,428 & 0,386 & 0,835 & 0,862 & 0,839 \\
2015 & 1,124 & 0,571 & 0,545 & 0,878 & 0,865 & 0,876 \\
2016 & 1,063 & 0,700 & 0,477 & 0,902 & 0,872 & 0,999 \\
2017 & 0,512 & 0,678 & 0,478 & 0,893 & 0,770 & 1,067 \\
2018 & 0,954 & 0,673 & 0,623 & 0,862 & 0,819 & 1,129 \\
2019 & 0,996 & 0,662 & 0,716 & 0,989 & 0,740 & 1,179 \\
Average & $\mathbf{0 , 9 1 1 9}$ & $\mathbf{0 , 5 3 1 2}$ & $\mathbf{0 , 4 5 7 4}$ & $\mathbf{0 , 8 1 2}$ & $\mathbf{0 , 8 5 2 1}$ & $\mathbf{0 , 9 6 7 3}$ \\
\hline
\end{tabular}

In comparison with the countries in its internal years Turkey has the highest value in terms of average. It is seen that it has a competitive advantage in the field of Paper and Paper Products industry against BRICS countries. Turkey is followed by Brazil and South Africa. Changes occurring in the country in the years when it is observed that increased $22.5 \%$ between the years 20102019 at the level of Turkey's competitiveness. Especially in recent years, it can be clearly seen that it has exceeded the accepted value of 1 in 2017, 2018 and 2019 and is in an increasing trend in this direction. With the BRICS countries in terms of foreign trade data owned by Turkey Paper and Paper Products are in position to compete in the industrial area has a structure.
Brazil, which ranks second in terms of average values, has achieved an $11 \%$ increase in competitive power over the years. It could not maintain the competitive advantage it had achieved in 2015 and 2016.

South Africa reduced its competitiveness value in 2010 in 2019 and showed a decline of $-25 \%$ in annual average. In general, South Africa, which does not have a competitive value of 1 or more, shows a negative situation in the field of Paper and Paper Products Industry.

China, which has been effective in the world economy in recent years, has a competitive position far from expected in the field of Paper and Paper Products Industry. The competitive advantage it has in many different areas is not seen in this product group. Considering the change over the years, it can be seen that China, which has increased by $81 \%$, will have a say in this field in the near future.

Russia and India share the last places in the ranking of competitive advantage in this product group. When it is considered that both countries showed annual growth (in Russia 100\% India 124\%) between Paper and Paper Products Industry in the BRICS countries and Turkey is seen that there will be serious competition to the war. Analysis results of Wood and Wood Products Industry sectors are shown in Table 8.

When Table 8, which includes the competitiveness of countries in the field of Wood and Wood products industry, is examined, it is clearly seen that Russia has a significant competitive advantage in this field in terms of both annual average value and values in all years. Brazil and China follow Russia.

Russia increased its competitiveness value in $2010(2,183>1)$ by $30 \%$ in $2019(2,839>1)$. During this period, Brazil showed an increase of $33 \%$ and showed that it was a significant power in competition..

Table 8. BRICS countries and Turkey: Wood and Wood Products Industry.

\begin{tabular}{|c|c|c|c|c|c|c|}
\hline Years & Brazil & Russia & Indian & China & South Africa & Turkey \\
\hline 2010 & 1,351 & 2,183 & 0,105 & 0,870 & 0,884 & 0,715 \\
\hline 2011 & 1,124 & 2,043 & 0,110 & 0,906 & 0,756 & 0,733 \\
\hline 2012 & 1,215 & 2,005 & 0,139 & 0,939 & 0,745 & 0,674 \\
\hline 2013 & 1,199 & 2,014 & 0,151 & 0,836 & 0,688 & 0,691 \\
\hline 2014 & 1,365 & 2,136 & 0,152 & 0,846 & 0,754 & 0,741 \\
\hline 2015 & 1,584 & 2,459 & 0,215 & 0,830 & 0,816 & 0,642 \\
\hline 2016 & 1,593 & 2,856 & 0,191 & 0,803 & 0,775 & 0,592 \\
\hline 2017 & 1,649 & 2,858 & 0,189 & 0,778 & 0,772 & 0,628 \\
\hline 2018 & 1,745 & 2,638 & 0,176 & 0,785 & 0,814 & 0,640 \\
\hline 2019 & 1,794 & 2,839 & 0,205 & 0,747 & 0,795 & 0,720 \\
\hline Average & 1,4619 & 2,4031 & 0,1633 & 0,834 & 0,7799 & 0,6776 \\
\hline
\end{tabular}

China and South Africa, which can provide an alternative to these two countries, showed a decrease of approximately $14 \%$ and $10 \%$ within this period and showed that they were losing power in competition. India's increase in this area remained far from a competitive position. 
Turkey has managed to maintain its competitiveness although that experience increases and decreases in the studied years. Turkey in this area who wants to take part in the BRICS countries are quite difficult to compete with Russia and Brazil.

\section{CONCLUSION}

Technological infrastructure and power that Turkey has experienced production Paper and Paper Products are qualities that can have a significant competitive advantage the BRICS countries across the industry. The analysis, which has adopted a position on the standard values in some years it was increasing its strength over the years indicate that Turkey's power in the market may be effective in this area. Paper and paper products with the support of Turkey will be held in the investment industry and will have an important place in the economic growth of the sector and will consist seems to be able to access the production center of Turkey in the world order. Turkey, paper and paper products are in a strong position in the industrial area opposite the BRICS countries. Turkey is in the paper and paper products industry can compete with Brazil and South Africa.

In the field of wood and wood products, the undisputed superiority of Russia and Brazil is seen in the analysis results due to the raw material availability they have among the BRICS countries. There is no country that can rival these two countries within the scope of the years examined. Turkey should act in this area and knowing the position which should encourage rational investment resources.

\section{ACKNOWLEDGMENTS}

This study was presented in ORENKO 2020 held by Karadeniz Technical University, Trabzon.

\section{REFERENCES}

Atabay Baytar, R. (2012). The Determinants of Trade Volume Between Turkey and BRIC Countries: A Gravity Mofel Analysis, İstanbul Commerce University. Journal of Social Sciences, 11(21), 403-424.

Ateş, D. (2012). International Organizations Organizational Logic of States, Bursa: Dora Publications.

Balassa, B. (1965). Trade Liberalization and Revealed Comparative Advantage. The Manchester School of Economic and Social Studies, 33(2), 99-123.
Chen, R. (2003). China Perceives America: Perspectives of International Experts. Journal of Comtemporary China, 12(35), 285-297.

Çelik, M. (2017). Sovereign Equality of States: An International Relations Myth, Ankara: Nobel Academic Publishing.

Liesner, H.H. (1958). The European Common Market and British Industry. Economic Journal, 68, 302-16.

O'Neill, J. (2001). Building Better Global Economic BRICs. Los Angeles: Goldman Sachs.

Önder, E. (2019). Some Main Index Framework in Turkey / BRICS Comparative Analysis. Policy Brief, 67, 1-17.

Öniş, Z. \& Kutlay, M. (2015). Democratic BRICS Countries: New Actors of Global Governance. Analist, 20-23.

Poyraz, M. (2019). BRICS: Is it a Search For an Alternative Order? Suleyman Demirel University Visionary Journal, 10(24), 434-449.

Sezer, S. (2018). The Effectiveness of Orthodox and Heterodox Economic Policies in the Elimination of Foreing Trade Deficit: The BRICS Countries and Turkey Comparison. Turkish Studies, 13(30), $387-420$.

Trade Map. (2020). www.trademap.org , Date of Access September 2020.

Wilson, D. \& Purushothaman, R. (2003). Dreaming with BRICs: The Path to 2050, Los Angeles: Goldman Sachs. 